\title{
Kompetensi, Independensi, Bukti Audit, dan Kualitas Hasil Audit Internal pada Inspektorat Kementerian Koperasi dan Usaha Kecil dan Menengah
}

\author{
Nungki Ayu Kusuma ${ }^{1}$, Darmansyah ${ }^{2}$ \\ ${ }^{1}$ Universitas ... \\ ${ }^{2}$ Universitas Pancasila, Jl. Srengseng Sawah, Jagakarsa, Jakarta Selatan, 12640
}

INFO ARTIKEL

JEL Classsification:

M40

M42

Keywords:

competency,

independency, audit

evidence, and quality

of internal audit result.

\begin{abstract}
This research analyzes the influence of competency, independency, and audit evidence on the quality of internal audit results at the Inspectorate of the Ministry of Cooperatives and Small and Medium Enterprise Republic of Indonesia Republic of Indonesia. The population in this research auditor Inspectorate Ministry of Cooperatives and Small and Medium Enterprise Republic of Indonesia, as many as 32 people auditors. The sampling technique is done by using saturated sampling method so that the sample used is the entire population. The data used is the primary data with the distribution of questionnaires to all respondents. The testing is done with multiple regressin test. Particially, competency has positive influence to the quality of internal audit result. Independency and audit evidence particially don't influence quality of internal audit result in Inspectorate of Ministry of Cooperatives and Small and Medium Enterprise Republic of Indonesia Republic of Indonesia.
\end{abstract}

\begin{abstract}
ABSTRAK
Penelitian ini menganalisa pengaruh kompetensi, independensi, dan bukti audit terhadap kualitas hasil audit internal pada Inspektorat Kementerian Koperasi dan Usaha Kecil dan Menengah Republik Indonesia. Populasi dalam penelitian ini auditor Inspektorat Kementerian Koperasi dan Usaha Kecil dan Menengah Republik Indonesia, yaitu sebanyak 32 orang auditor. Teknik pengambilan sampel dilakukan dengan menggunakan metode sampel jenuh sehingga sampel yang digunakan adalah seluruh populasi yang ada. Data yang digunakan merupakan data primer dengan penyebaran kuesioner ke seluruh responden. Pengujian dilakukan dengan uji regresi berganda. Secara masingmasing, kompetensi memberikan pengaruh yang positif terhadap kualitas hasil audit internal. Independensi dan bukti aduit secara terpisah tidak memberikan pengaruh terhadap kualitas hasil audit internal di Inspektorat Kementerian Koperasi dan Usaha Kecil dan Menengah Republik Indonesia.
\end{abstract}

\section{Pendahuluan}

Otonomi daerah yang diberlakukan pada awal tahun 2001 merupakan suatu perubahan atas sistem pengelolaan keuangan daerah. Dengan adanya otonomi daerah tersebut, pemerintah daerah mempunyai kewenangan seluasluasnya dalam pengelolaan keuangan daerah dengan adanya sistem baru tersebut. Dengan diberlakukannya sistem otonomi daerah, intansi pemeritah diminta untuk dapat menunjukkan kinerjanya kepada para stakeholder dan dalam hal ini adalah masyarakat secara luas. Kinerja sektor publik dapat terlihat dari tingkat akuntabiltas

*Email Korespondensi: 'ayu.kusuma4@gmail.com, 2darmansyah@univpancasila.ac.id 
instansi-instansi pemerintah. Dengan adanya akuntabilitas yang baik, pengelolaan yang baik (good governance) akan terwujud.

Kepemerintahan yang baik (good governance) tentu saja harus didukung dengan adanya pengawasan, fpengendalian, dan pemeriksaan. Kegiatan pengawasan merupakan kegiatan yang dilakukan oleh pihak luar eksekutif, yaitu masyarakat dan Dewan Perwakilan Rakyat Daerah (DPRD) untuk mengawasi kinerja pemerintahan. Pengendalian (control) adalah mekanisme yang dilakukan oleh eksekutif untuk menjamin bahwa sistem dan kebijakan manajemen dilaksanakan dengan baik sehingga tujuan organisasi dapat tercapai. Sedangkan pemeriksaan (audit) merupakan kegiatan yang dilakukan oleh pihak yang memiliki independensi dan memiliki kompetensi profesional untuk memeriksa apakah hasil kinerja pemerintah telah sesuai dengan standar yang ditetapkan.

Proses pemeriksaan (audit) di Indonesia dilaksanakan oleh seorang auditor pemerintah yang terdiri dari Inspektorat Jenderal Kementerian, Satuan Pengawas Intern Pemerintah (SPIP) di lingkungan Lembaga Negara dan BUMN/BUMD, Inspektorat Wilayah Provinsi, Inspektorat Wilayah Kabupaten/Kota, Badan Pengawas Keuangan dan Pembangunan (BPKP) dan Badan Pemeriksa Keuangan (BPK) yang merupakan lembaga pemeriksa eksternal yang independen.

Implementasi good governance $\mathrm{di}$ lingkungan pemerintahan, pemerintah harus melakukan reformasi dalam segala aspek pengelolaan keuangan tingkat pusat dan daerah atau yang disebut dengan dana dekonsentrasi. Salah satu langkah yang harus dilakukan pemerintah pusat adalah melakukan reformasi audit baik internal maupun eksternal dalam penyelenggaraan pemerintahan. Melalui reformasi audit ini diharapkan kegiatan audit di lingkungan instansi pemerintah dapat berjalan lebih maksimal, sehingga dapat mengurangi terjadinya kesalahan prosedur dan tindak pidana yang sering dilakukan oleh auditee yang berdampak pada kerugian negara. Berdasarkan Peraturan Pemerintah Nomot 79 Tahun 2005 Pasal 24 pengawasan terhadap urusan pemerintah daerah dilaksanakan oleh Aparat Pengawasan Intern Pemerintah (APIP) sesuai dengan fungsi dan kewenangnannya. Aparat Pengawasan Intern Pemerintah (APIP) adalah Inspektorat Jenderal Kementerian, Unit pengawasan Lembaga Pemerintah Non Kementerian, Inspektorat Provinsi, dan Inspektorat Kebupaten/Kota.

Pengawasan intern yang dilakukan oleh Aparat Pengawasan Pemerintah (APIP) yang terdapat dalam Sistem Pengendalian Intern Pemerintah (SPIP) terdiri dari audit, review, evaluasi, pemantauan, dan kegiatan pengawasan lainnya. Pengawasan berfungsi membantu agar sasaran yang ditetapkan oleh organisasi dapat tercapai. Di samping itu, pengawasan berfungsi mendeteksi secara dini terjadinya penyimpangan pelaksanaan, penyalahgunaan wewenang, pemborosan dan kebocoran (Sukriah, 2010). Selain fungsi yang disampaikan oleh Sukriah (2010) tersebut, pengawas intern juga berfungsi sebagai pembina dalam pelaksanaan kegiatan pengelolaan keuangan suatu organisasi. Pembinaan yang diberikan oleh pengawas intern apabila dijalankan dengan baik oleh pengelola keuangan, maka penyimpangan, penyalahgunaan dan pemborosan akan dapat diminimalisir. Pembinaan dapat dikatakan baik apabila pihak pembina maupun pihak yang dibina mampu saling bekerja sama.

Kesuksesan pelaksanaan fungsi-fungsi pengawas intern salah satu dapat terlihat dari hasil pemeriksaan yang dilakukan oleh pengawas eksternal, yaitu Badan Pengawas Keuangan (BPK). Kementerian Koperasi dan UKM merupakan salah satu Kementerian yang mampu mempertahankan opini Wajar tanpa Pengecualian (WTP) selama 2 (dua) tahun berturut-turut pada tahun 2011 dan 2012. Namun, pada tahun 2014, kinerja Kementerian Koperasi dan UKM mengalami penurunan yang terlihat dari opini BPK di tahun tersebut 
berubah menjadi Wajar Dengan Pengecualian (WDP) yang diakibatkan beberapa kasus dalam pengadaan barang dan jasa.

Penurunan opini BPK di tahun 2013, salah satu penyebabnya adalah kegagalan fungsi yang dimiliki oleh pengawas intern. Dalam melakukan fungsi dan tugasnya, tentu saja pengawas intern memiliki kendala dan hambatan baik dari diri pribadi ataupun dari lingkungan sekitar. Beberapa kendala dihadapi oleh pemeriksa internal dalam melaksanaan pemeriksaan. Kendala yang dihadapi antara lain adanya rasa kekeluargaan, kebersamaan, dan rasa pertimbangan manusiawi dikarenakan auditee merupakan pihak yang sudah dikenal baik. Kendala yang lain yang dihadapi adalah kendala yang terkait dengan kualitas pemeriksa internal itu sendiri. Kendalakendala tersebut tentu saja dapat mempengaruhi kualitas hasil audit yang dihasilkan oleh para pemeriksa internal.

Kualitas audit yang dihasilkan oleh Inspektorat Kementerian Koperasi dan UKM
RI setiap tahunnya berbeda-beda untuk auditee Unit Kerja Pusat dan Satuan Kerja (Satker) Tingkat Provinsi. Jumlah auditee untuk Unit Kerja Pusat dari tahun 2010 hingga 2015 sama, yaitu sebanyak 11 Unit Kerja. Sedangkan jumlah auditee untuk Satker Tingkat Provinsi dari tahun 2010 hingga 2014 sebanyak 33 Satker dan pada tahun 2015 menjadi 34 Satker, yaitu bertambahnya Provinsi Kalimantan Utara karena adanya pemekaran wilayah. Dengan kata lain, jumlah auditee Inspektorat Kementerian Koperasi dan UKM pada tahun 2010 sampai dengan 2014 sebanyak 44 auditee dan pada tahun 2015 menjadi 45 auditee. Kualitas audit yang dihasilkan salah satunya dapat terlihat dari berapa banyak temuan yang dihasilkan. Dalam 6 tahun berturut-turut, jumlah kelemahan yang ditemukan dari 2 jenis auditee berbeda-beda. Gambaran atas jumlah auditee dan temuan yang diperoleh atas pemeriksaan Inspektorat Kementerian Koperasi dan UKM selama 6 tahun adalah sebagai berikut :

\section{Tabel 1. Jumlah Temuan Inspektorat Kementerian Koperasi dan UKM}

Tahun 2010 - 2015

\begin{tabular}{|c|c|c|c|c|c|c|c|c|c|c|c|c|}
\hline \multirow[b]{2}{*}{ Auditee } & \multicolumn{2}{|c|}{2010} & \multicolumn{2}{|c|}{2011} & \multicolumn{2}{|c|}{2012} & \multicolumn{2}{|c|}{2013} & \multicolumn{2}{|c|}{2014} & \multicolumn{2}{|c|}{2015} \\
\hline & $\begin{array}{l}\text { Jumlah } \\
\text { Auditee }\end{array}$ & $\begin{array}{l}\text { Jumlah } \\
\text { Temuan }\end{array}$ & $\begin{array}{l}\text { Jumlah } \\
\text { Auditee }\end{array}$ & $\begin{array}{l}\text { Jumlah } \\
\text { Temuan }\end{array}$ & $\begin{array}{l}\text { Jumlah } \\
\text { Auditee }\end{array}$ & $\begin{array}{l}\text { Jumlah } \\
\text { Temuan }\end{array}$ & $\begin{array}{l}\text { Jumlah } \\
\text { Auditee }\end{array}$ & $\begin{array}{l}\text { Jumlah } \\
\text { Temuan }\end{array}$ & $\begin{array}{l}\text { Jumlah } \\
\text { Auditee }\end{array}$ & $\begin{array}{l}\text { Jumlah } \\
\text { Temuan }\end{array}$ & $\begin{array}{l}\text { Jumlah } \\
\text { Auditee }\end{array}$ & $\begin{array}{l}\text { Jumlah } \\
\text { Temuan }\end{array}$ \\
\hline Unit Kerja Pusat & 11 & 77 & 11 & 76 & 11 & 73 & 11 & 72 & 11 & 75 & 11 & 74 \\
\hline Satuan Kerja Tingkat Provinsi & 33 & 212 & 33 & 220 & 33 & 216 & 33 & 241 & 33 & 215 & 34 & 219 \\
\hline Total & 44 & 289 & 44 & 296 & 44 & 289 & 44 & 313 & 44 & 290 & 45 & 293 \\
\hline
\end{tabular}

Sumber : Inspektorat Kementerian Koperasi dan UKM

Menurut Sukriah (2010), kualitas yang dimaksud adalah sikap dan perilaku, kemampuan aparat pengawasan dalam melakukan pemeriksaan, sehingga pengawasan yang dilaksanakan dapat berjalan secara wajar, efektif, dan efisien. Sedangkan dalam penelitian De Angelo (1981) yang tertuang dalam penelitian Tjun (2012) dinyatakan bahwa kualitas audit merupakan probabilitas auditor akan menemukan dan melaporkan pelanggaran pada sistem akuntansi klien.

Pengguna laporan hasil pemeriksaan yang dilakukan oleh APIP menginginkan adanya aparat pengawasan yang bersih, berwibawa, tertib dan teratur dalam melaksanakan tugas dan fungsinya sesuai dengan ketentuan dan normal yang berlaku. Norma dan ketentuan yang berlaku bagi auditor intern pemerintah terdiri dari Kode Etik APIP dan Standar Audit APIP. Kode Etik yang dimaksud untuk menjaga perilaku APIP dalam melaksanakan tugasnya. Sedangkan Standar Audit dimaksudkan untuk menjaga kualitas hasil audit yang dilaksanakan APIP. Dengan adanya aturan tersebut, masyarakat atau pengguna laporan dapat menilai sejauh mana auditor pemerintah telah bekerja sesuai dengan standar dan etika yang telah ditetapkan. 
Dalam penelitian yang telah dilakukan oleh Sukriah (2010) terhadap auditor di Inspektorat Se- Pulau Lombok, kompetensi memberikan pengaruh yang signifikan dan positif terhadap kualitas hasil audit. Untuk independensi memberikan pengaruh yang tidak signifikan dan negative terhadap kualitas hasil audit. Ketidaksignifikanan disebabkan karena pada saat penyusunan program pemeriksaan masih ada intervensi dari pimpinan untuk menentukan, mengeliminasi atau memodifikasi bagian-bagian tertentu yang akan diperiksa. Selain itu pada saat penyusunan laporan masih sering menggunakan bahasa atau istilah yang menimbulkan multi tafsir.

Tjun Tjun (2012) dalam penelitian yang dilakukan kepada seluruh auditor KAP yang berada di Jakarta Pusat menyatakan bahwa kompetensiauditorberpengaruhterhadap kualitas hasil audit, sedangkan untuk independensi tidak berpengaruh terhadap kualitas hasil audit. Namun secara bersamaan, kompetensi dan independensi memberikan pengaruh terhadap kualitas hasil audit. Bolang (2013) melakukan penelitian untuk melihat pengaruh kompetensi, independensi, dan pengalaman terhadap kualitas audit aparat Inspektorat Kota Tomohon. Dalam penelitiannya, ketiga variabel independen secara simultan berpengaruh positif terhadap kualitas audit. Untuk independensi dan pengalaman kerja auditor berpengaruh positif dan signifikan terhadap kualitas audit, sedangkan kompetensi berpengaruh positif namun tidak signifikan.

Penelitian yang bertujuan untuk menganalisis faktor-faktor yang mempengaruhi kualitas audit juga dilakukan oleh Mabruri dan Winarna (2010). Yang menjadi objek dalam penelitian ini adalah semua Pegawai Negeri Sipil (PNS) yang bekerja pada Inspektorat di Kabupaten/Kota Surakarta, Karanganyar, Sukoharjo, dan Wonogiri. Dari penelitian ini diperoleh hasil bahwa secara serentak seluruh variabel independen (independensi, objektifitas, pengalaman kerja, pengetahuan, dan integritas auditor) berpengaruh signifikan terhadap kualitas audit. Secara parsial, objektifitas, pengalaman kerja, pengetahuan, dan integritas auditor berpengaruh signifikan terhadap kualitas audit. Namun, untuk independensi tidak memberikan pengaruh yang signifikan terhadap kualitas audit.

Penelitian yang berkaitan dengan bukti audit pernah dilakukan oleh Fitriani dan Chariri (2014) tentang Pengaruh Tipe Klien dan Tipe Komunikasi Terhadap Pengumpulan Bukti Audit (Studi Persepsi Auditor KAP di Jawa Tengah). Dari hasil penelitian ini diperoleh bahwa tipe klien berpengaruh signifikan negatif terhadap pengumpulan bukti klien, tipe komunikasi juga berpengaruh signifikan negatif terhadap pengumpulan bukti audit, dan tipe komunikasi memperkuat secara signifikan pengaruh tipe klien terhadap pengumpulan bukti audit. Selain itu, Kinantya (2015) juga pernah melakukan penelitian terkait dengan bukti audit, yaitu Pengaruh Pengalaman, Profesionalisme, dan Resiko Audit Terhadap Bukti Audit Kompeten yang Cukup. Responden dalam penelitian ini adalah para akuntan KAP di Bandung. Hasil dari penelitian ini adalah pengalaman auditor berpengaruh siginikan positif terhadap bukti audit kompeten yang cukup, profesionalisme auditor berpengaruh siginikan positif terhadap bukti audit kompeten yang cukup, resiko audit yang dapat dikendalikan berpengaruh siginikan positif terhadap bukti audit kompeten yang cukup, dan secara bersamaan ketiga variabel memberikan pengaruh yang signifikan positif terhadap bukti audit kompeten yang cukup.

Penelitian ini merupakan pengembangan dari penelitian yang dilakukan oleh Tjun Tjun (2012) tentang Pengaruh Kompetensi dan Inpendensi Auditor Terhadap Kualitas Audit. Peneliti menggunakan objek yang berbeda dan adanya penggunaan variabel independen, yaitu bukti audit. Pada penelitian sebelumnya, yang menjadi objek penelitian adalah seluruh auditor yang berbeda di Jakarta Pusat dengan asumsi setiap KAP memiliki kurang lebih 5 orang auditor. Dan pada penelitian sebelumnya variabel bukti audit dijadikan sebagai variabel dependen. 
Sedangkan pada penelitian ini, yang menjadi objek penelitian adalah Inspektorat Kementerian Koperasi dan UKM RI dan variabel bukti audit dijadikan variabel independen.

\section{Telaah Teori dan Pengembangan Hipotesis}

\section{Agency Theory}

Agency Theory menjelaskan hubungan kontraktual antara prinsipal dan agen. Agency Theory ini muncul karena adanya perbedaan kepentingan antara prinsipal dan agen. Agency Theory memiliki 2 tujuan, yaitu yang pertama bertujuan untuk meningkatkan kemampuan prinsipal dan agen dalam menilai lingkungan ketika harus mengambil keputusan. Tujuan yang kedua yaitu mengevaluasi keputusan yang sudah diambil agar mempermudah pengalokasian hasil antara prinsipal dengan agen sesuai dengan perjanjian kedua belah pihak tersebut.

Hubungan agensi menimbulkan biaya bagi prinsipal. Biaya-biaya tersebut merupakan biaya untuk memonitoring oleh prinsipal, biaya kontrak, dan biaya kerugian lainnya (Schroeder, 2005:115).

\section{Behavioral Accounting}

Behavioral Accounting (Akuntansi Keperilakuan) merupakan suatu tudi tentang perilaku akuntan atau non-akuntan yang dipengaruhi oleh fungsi-fungsi akuntansi dan pelaporan (Suartana, 2010). Akuntansi keperilakuan menekankan pada pertimbangan dan pengambilan keputusan akuntan dan auditor, pengaruh dari fungsi akuntansi (misalnya partisipasi penganggaran, ketetatan anggaran, dan karakter system informasi) dan fungsi auditing terhadap perilaku, misanya pertimbangan (judgement) dan pengambilan keputusan dan kualitas pertimbangan dan keputusan auditor, dan pengaruh dari keluaran dari fungsi-fungsi akuntansi berupa laporan keuangan terhadap pertimbangan pemakai dan pengambilan keputusan (Bamber, 1993).

\section{Hubungan Antara Kompetensi dengan Kualitas Hasil Audit Internal}

Kompetensi merupakan suatu karakteristik yang mendasar dari seorang individu, yaitu penyebab yang terkait dengan acuan kriteria tentang kinerja yang efektif " $A$ competency is an underlying characteristic of an individual that is causally related to criterion-referenced effective and/or superior performance in a job or situation" (Spencer \& Spencer, 1993).

Hasil penelitian yang dilakukan oleh Ardini (2010) menyatakan bahwa tingkat kemampuan yang dimiliki oleh auditor akan menunjang kualitas audit yang mereka hasilkan. Semakin tinggi tingkat komptensi yang dimiliki auditor maka akan semakin tinggi pula tingkat kualitas audit yang mereka hasilkan. Berdasarkan hal tersebut, maka hipotesis yang diajukan dalam penelitian ini sebagai berikut:

H1 : Kompetensi berpengaruh terhadap kualitas hasil audit internal

\section{Hubungan Antara Independensi dengan Kualitas Hasil Audit Internal}

Independensi menurut Mulyadi (2010) dapat diartikan sikap mental yang bebas dari pengaruh, tidak dikendalikan oleh pihak lain, tidak tergantung pada orang lain. Independensi juga berarti adanya kejujuran dalam diri auditor dalam mempertimbangkan fakta dan adanya pertimbangan yang objektif tidak memihak dalam diri auditor dalam merumuskan dan menyatakan pendapatnya.

Hasil penelitian yang dilakukan oleh Ardini (2010), Badjuri (2011), dan Bolang (2013) menyatakan bahwa independensi memberikan pengaruh yang signifikan positif terhadap kualitas audit. Berdasarkan hal tersebut, maka hipotesis yang diajukan dalam penelitian ini sebagai berikut:

$\mathrm{H} 2$ : Independensi berpengaruh terhadap kualitas hasil audit internal 


\section{Hubungan Antara Bukti Audit dengan Kualitas Hasil Audit Internal}

Mulyadi (2010) mendefinisikan bukti audit sebagai segala informasi yang mendukung angka-angka untuk informasi lain yang disajikan dalam laporan keuangan, yang dapat digunakan oleh auditor sebagai dasar untuk menyatakan pendapat.

Bukti audit yang diberikan oleh auditee sangat membantu auditor dalam proses audit. Dalam penelitian ini, peneliti menambahkan variabel bukti audit sebagai variabel penelitian dikarenakan belum ada penelitianpenelitian yang terpublikasi sebelumnya yang menggunakan variabel ini sebagai variabel independen. Penelitian sebelumnya yang dilakukan oleh Fitriani dan Chariri (2014) dan Kinantya (2015) menggunakan variabel bukti audit sebagai variabel dependen. Berdasarkan hal tersebut, maka hipotesis yang diajukan dalam penelitian ini sebagai berikut:

H3 : Bukti Audit berpengaruh terhadap kualitas hasil audit internal

\section{Metode Penelitian}

Populasi yang digunakan dalam penelitian ini adalah seluruh auditor di lingkungan Kementerian Koperasi dan UKM, yaitu sebanyak 32 orang. Karena jumlah populasi sedikit, maka semua populasi akan dijadikan sampel penelitian. Metode pemilihan sampel yang digunakan adalah metode sensus, dimana penyebaran kuesioner dilakukan pada semua populasi.

Studi kepustakaan dilaksanakan dalam rangka mengumpulkan fakta, informasi, dan teori-teori yang relevan dengan permasalahan yang diteliti maupun variabel-variabel yang digunakan dalam penelitian baik bersumber dari buku-buku ilmiah, penelitian sebelumnya yang terkait, peraturan-peraturan pemerintah terkait, laporan kegiatan di lingkup obyek penelitian, dan sumber lainnya baik yang tercetak maupun berupa data elektronik.
Data utama penelitian ini diperoleh melalui penelitian primer. Peneliti memperoleh data langsung dari pihak pertama (data primer). Dalam penelitian ini, yang menjasi subyek peneltian dalah apara auditor di lingkungan Inspektorat Kementerian Koperasi dan UKM RI. Peneliti memperoleh data dengan mengirimkan kuesioner kepada para auditor secara langsung ataupun melalui perantara.

Sumber data yang digunakan adalah data primer. Dalam penelitian ini data primer berupa persepsi para responden atas berbagai pertanyaan dalam kuesioner mengenai variabel terkait. Hal ini dikarenakan berhubungan dengan penerimaan seorang auditor terhadap suatu perilaku oleh karena itu harus dilakukan suatu pengumpulan pendapat dari para auditor dengan data yang valid. Data tersebut merupakan jawaban atas kuesioner yang dibagikan kepada responden dalam hal ini auditor yang bekerja di Inspektorat Kementerian Koperasi dan UKM RI.

Sumber data dalam penelitian ini adalah skor dari masing-masing indikator variabel yang diperoleh dari pengisian kuesioner yang telah disebar dan diisi oleh auditor di Inspektorat Kementerian Koperasi da UKM RI. Variabelvariabel yang digunakan di atas menggunakan kuesioner dan diukur dengan skala Likert 1-5 untuk setiap bobot pertanyaan, yaitu :
a. Sangat Setuju (SS)
$=$ skor 5
b. Setuju (S)
$=$ skor 4
c. Kurang Setuju (KS)
$=$ skor 3
d. Tidak Setuju (TS) = skor 2
e. Sangat Tidak Setuju (STS) $=$ skor 1 
Tabel 2. Variabel, Sub Variabel, dan Indikator Penelitian

\begin{tabular}{|c|c|c|c|}
\hline Variabel & Sub Variabel & Indikator & Skala \\
\hline \multirow[t]{2}{*}{ Kompetensi } & $\begin{array}{l}\text { Tingkat } \\
\text { Pengetahuan }\end{array}$ & $\begin{array}{l}\text { a. Pengetahuan standar akuntansi dan audit } \\
\text { internal } \\
\text { b. Pengetahuan program kegiatan auditee } \\
\text { c. Pengetahuan pendidikan formal } \\
\text { d. Pengetahuan dari pelatihan di bidangan audit } \\
\text { e. Pengetahuan dasar-dasar audit internal } \\
\text { f. Sertifikasi keahlian }\end{array}$ & Ordinal \\
\hline & Pengalaman & $\begin{array}{l}\text { a. Lamanya melakukan audit } \\
\text { b. Jumlah auditee yang telah diaudit }\end{array}$ & Ordinal \\
\hline \multirow[t]{3}{*}{ Independensi } & $\begin{array}{l}\text { Pelaksanaan } \\
\text { Audit }\end{array}$ & $\begin{array}{l}\text { a. Hubungan dengan auditee } \\
\text { b. Lamanya mengaudit di tempat yang sama } \\
\text { c. Kerjasama dengan auditee } \\
\text { d. Pemberian peringatan/permintaan dari } \\
\text { Pimpinan }\end{array}$ & Ordinal \\
\hline & $\begin{array}{l}\text { Penyusunan } \\
\text { Program }\end{array}$ & $\begin{array}{l}\text { a. Campur tangan dari Pimpinan (Inspektur) } \\
\text { b. Campur tangan auditee }\end{array}$ & Ordinal \\
\hline & Pelaporan & $\begin{array}{l}\text { a. Bebas dari bahas dan istilah yang } \\
\text { menimbulkan multi tafsir } \\
\text { b. Bebas dari pihak tertentu }\end{array}$ & Ordinal \\
\hline \multirow[t]{6}{*}{ Bukti Audit } & $\begin{array}{l}\text { Independensi } \\
\text { Pemberian } \\
\text { Informasi }\end{array}$ & $\begin{array}{l}\text { Pemeriksaan independensi dari pemberi bahan } \\
\text { bukti }\end{array}$ & Ordinal \\
\hline & $\begin{array}{l}\text { Efektifiktas } \\
\text { Pengendalian } \\
\text { Internal Klien }\end{array}$ & $\begin{array}{l}\text { a. Unit Kerja/Satker sudah memiliki } \\
\text { pengendalian internal yang efektif } \\
\text { b. Bahan bukti yang diberikan lebih andal }\end{array}$ & Ordinal \\
\hline & $\begin{array}{l}\text { Pengetahuan } \\
\text { Langsung } \\
\text { Auditor }\end{array}$ & $\begin{array}{l}\text { a. Pengetahuan mendalam untuk setiap bahan } \\
\text { bukti yang diperiksa } \\
\text { b. Penilaian untuk setiap bahan bukti audit } \\
\text { yang diperiksa }\end{array}$ & Ordinal \\
\hline & $\begin{array}{l}\text { Kualifikasi } \\
\text { Individu yang } \\
\text { Memberikan } \\
\text { Informasi }\end{array}$ & $\begin{array}{l}\text { a. Keandalan bukti audit dengan pemeriksaan } \\
\text { langsung } \\
\text { b. Sumber bukti yang diperoleh }\end{array}$ & Ordinal \\
\hline & $\begin{array}{l}\text { Tingkat } \\
\text { Objektifitas }\end{array}$ & $\begin{array}{l}\text { a. Ketidakmudahan untuk cepat percaya pihak } \\
\text { lain } \\
\text { b. Bukti objektif lebih dapat diandalkan } \\
\text { dibandingkan dengan bahan bukti yang } \\
\text { memerlukan penilaian }\end{array}$ & Ordinal \\
\hline & Ketepatan Waktu & $\begin{array}{l}\text { a. Pengumpulan bukti sesuai dengan waktu } \\
\text { yang telah ditentukan } \\
\text { b. Tetap melanjutkan pengumpulan bahan bukti } \\
\text { walau waktu sudah habis }\end{array}$ & Ordinal \\
\hline
\end{tabular}




\begin{tabular}{lllc}
\hline \multicolumn{1}{c}{ Variabel } & \multicolumn{1}{c}{ Sub Variabel } & \multicolumn{1}{c}{ Indikator } & Skala \\
\hline Kualitas Hasil & Kesesuaian & a. Adanya review oleh atasan & Ordinal \\
Audit Internal & $\begin{array}{l}\text { Audit dengan } \\
\text { Standar Audit }\end{array}$ & b. Penatausahaan dokumen audit & \\
& Keakuratan & a. Keakuratan temuan audit & Ordinal \\
& Temuan Audit & b. Rekayasa temuan & \\
& Nilai & Ketepatan pemberian rekomendasi & Ordinal \\
& Rekomendasi & & \\
& Kejelasan isi & a. Laporan yang obyektif & Ordinal \\
& laporan & b. Kemudahan auditee memahami laporan & \\
& Manfaat Audit & Perbaikan kegiatan untuk berikutnya & Ordinal \\
\hline
\end{tabular}

Analisis deskriptif digunakan untuk mendeskripsikan variabel. Teknik analisis data dilakukan dengan uji regresi berganda. Pengujian regresi berganda dilakukan setelah uji validitas, uji reliabilitas dan uji asumsi klasik yang terdiri dari uji normalitas, uji heterokedastisita, dan uji multikolinearitas. Uji normalitas dilakukan dengan Uji Kolomogorov Smirnov. Uji validitas dilakukan dengan melihat nilai sig. 2-tailed. Uji reliabilitas dilakukan dengan menggunakan Cronbach's Alpha. Uji Multikolinearitas dilakukan dengan melihat angka VIF (Variance Inflaction Factor). Uji heterokedastisitas menggunakan Rank Spearman.

Uji $\mathrm{F}$ digunakan untuk melihat pengaruh ketiga variabel independen terhadap variabel dependen secara simultan. Uji Koefisien Determiansi (Adjusted $R$ Square) digunakan untuk mengetahui prosentase sumbangan pengaruh variabel independen secara serentak terhadap variabel dependen. Pengujian hipotesis
1 sampai dengan hipotesis 3 dilakukan dengan melihat hasil uji-t. Jika hasil uji-t menunjukkan nilai signifikansi $<0.05$ (pada $\alpha=5 \%$ ) pada hipotesis penelitian (H0 ditolak dan $\mathrm{H} 1$ diterima).

\section{Hasil Penelitian dan Pembahasan}

Penelitian ini bertujuan untuk menganalisis pengaruh kompetensi, independensi, dan bukti audit terhadap kualitas hasil audit internal. Jumlah responden yang ada sebanyak 32 responden namun 6 data merupakan data outlier sehingga sampel dianalisis sejumlah 26 data responden yang merupakan auditor Inspektorat Kementerian Koperasi dan UKM. Hasil uji validitas menunjukkan semua variabel valid. Hasil uji reliabilitas menunjukkan semua variabel dinyatakan reliabel. Hasil uji asumsi klasik menunjukkan distribusi nikai residual variabel adalah normal $0,711>0.05$. Deskripsi penelitian dirangkum pada tabel berikut :

\section{Tabel 3. Hasil Statistik Deskriptif}

\begin{tabular}{lrrrcr}
\hline & N & Minimum & Maximum & Mean & Std. Deviation \\
Kompetensi & 26 & 4,20 & 4,60 & 4,4192 &, 10590 \\
Independensi & 26 & 3,70 & 4,50 & 4,0538 &, 21020 \\
Bukti Audit & 26 & 4,09 & 4,64 & 4,3951 &, 13097 \\
Kualitas Hasil & 26 & 4,25 & 4,50 & 4,3942 &, 09146 \\
Audit & & & & & \\
Valid N (listwise) & 26 & & & & \\
\hline
\end{tabular}


Semua item memiliki nilai sig. 2 -tailed < 0,05 sehingga dinyatakan valid. Nilai Cronbach's Alpha untuk semua variabel $>0.6$ sehingga semua variabel dinyatakan reliabel. Nilai VIF untuk semua variabel independen $<10$ sehingga dinyatakan tidak terjadi multikolinearitas antar variabel. Ketiga variabel independen menghasilkan nilai sig.2-tailed $>0,05$ sehingga dinyatakan tidak terjadi heterokedastisitas.

Berdasarkan hasil uji-t, kompetensi berpengaruh terhadap terhadap kualitas hasil audit internal, sedangkan untuk independensi dan bukti audit tidak berpengaruh terhadap kualitas hasil audit internal secara parsial. Hasil uji determinasi $\left(\mathrm{R}^{2}\right)$ diperoleh nilai Adjusted $R$ Square $\left(\mathrm{R}^{2}\right)$ sebesar 0,209 sama dengan 20,9\%. Nilai tersebut mengandung arti bahwa variabel independen Kompetensi (X1), Independensi (X2), dan Bukti Audit (X3) memberikan pengaruh terhadap variabel dependen $(\mathrm{Y})$, yaitu Kualitas Hasil Audit Internal sebesar 20,9\%. Sedangkan sisanya sebesar 79,1\% dipengaruhi oleh variabel lain di luar model regresi ini.

Tabel 4. Rangkuman Hasil Pengujian

\begin{tabular}{lrrrr}
\hline Keterangan & \multicolumn{1}{c}{ B } & Std. Error & t-hitung & \multicolumn{1}{c}{ Sig. } \\
\hline Kompetensi & 0,361 & 0,167 & 2,162 & 0,042 \\
Independensi & $-0,076$ & 0,086 & $-0,887$ & 0.385 \\
Bukti Audit & $-0,297$ & 0,130 & $-2,282$ & 0.033 \\
Constant & 4,412 & 0,802 & & \\
R-Square & 0,304 & & & \\
Adjusted R-Square & 0,209 & & & \\
F-hitung & 3,200 & & & \\
Sig. F & 0.043 & & & \\
\hline
\end{tabular}

Hasil pengujian model penelitian dan hipotesis terangkum pada tabel berikut : $\mathrm{Y}=4,412+0,361 \mathrm{X} 1-0,076 \mathrm{X} 2-0,297 \mathrm{X} 3+\mathrm{e}$

Hasil persamaan di atas memiliki makna bahwa konstanta sebesar 4,412 menunjukkan bahawa ketika variabel independen, yaitu kompetensi, independensi dan bukti audit konstan, maka rata-rata nilai yang mempengaruhi variabel dependen, yaitu kualitas hasil audit internal sebesar 4,412. Nilai koefisien regresi kompetensi sebesar 0,361, menunjukkan bahwa setiap kenaikan 1 konstanta variabel kompetensi dengan variabel lainnya tetap, maka akan meningkatkan kualitas hasil audit internal sebesar 0,361. Koefisien bernilai positif menunjukkan bahwa semakin baik kompetensi yang dimiliki oleh auditor, maka akan semakin baik kualitas hasil audit yang dihasilkan.

Nilai koefisien independensi sebesar $-0,076$, menunjukkan bahwa setiap kenaikan 1 konstanta variabel independensi dengan variabel lainnya tetap, maka akan menurunkan kualitas hasil audit internal sebebsar 0,076. Koefisien bernilai negatir menunjukkan bahwa semakin tinggi nilai independensi yang dimiliki auditor, maka kualitas hasil audit yang dhasilkan akan menurun. Nilai koefisien bukti audit sebesar -0,297 menunjukkan bahwa setiap kenaikan 1 konstanta variabel bukti audit dengan variabel lain tetap, maka akan menurunkan kualitas hasil audit internal sebesar 0,297 . Koefisien bernilai negatif menujunkkan bahwa semakin baik bukti audit yang dperoleh, maka kualitas hasil audit yang dihasilkan akan semakin menurun.

\section{Pengaruh Kompetensi Terhadap Kualitas Hasil Audit Internal}

Hasil pengolahan data menyimpulkan bahwa untuk hipotesis pertama membuktikan bahwa kompetensi auditor berpengaruh positif terhadap kualitas hasil audit internal, sehingga $\mathrm{H}_{\mathrm{a} 1}$ diterima. Dalam penelitian ini, kompetensi yang 
digunakan menggunakan tingkat pengetahuan dan pengalaman auditor Kementerian Koperasi dan UKM sebagai indikator. Tingkat pengetahuan yang dimiliki oleh para auditor di lingkungan Kementerian Koperasi dan UKM terus ditingkatkan karena terbukti dengan minat para auditor untuk melanjutkan program pendidikan formal di beberapa perguruan tinggi dan semakin banyaknya auditor yang mengikuti dan memperoleh sertifikasi keahlian dan training yang diadakan oleh Badan Pengawasan Keuangan dan Pembangunan (BPKP) maupun instansi lainnya.

Hal ini sejalan dengan penelitian yang dilakukan oleh Ardini (2010), dan Tjun Tjun (2012) yang menyatakan bahwa kompetensi memberikan pengaruh yang positif terhadap kualitas hasil audit. Semakin meningkatnya kompetensi yang dimiliki oleh auditor maka kualitas hasil audit internal pun juga akan semakin baik. Kompetensi yang diperlukan dalam proses audit tidah hanya berupa penguasaan terhadap standar akuntansi dan auditing, namun juga penguasaan terhadap objek audit. Selain itu juga dengan ada atau tidaknya program atau proses peningkatan keahlian dapat dijadikan sebagai indikator untuk mengukur kompetensi auditor.

\section{Pengaruh Independensi terhadap Kualitas Hasil Audit Internal}

Hasil pengujian hipotesis kedua membuktikan bahwa independensi tidak berpengaruh terhadap kualitas hasil audit internal, sehingga $\mathrm{H}_{\mathrm{a} 2}$ ditolak. Hal ini dikarenakan masih adanya campur tangan pimpinan dalam penyusunan program pengawasan dan pelaporan yang dilakukan oleh tim audit di lapangan. Selain itu dikarenakan masih adanya auditee yang diperiksa oleh tim audit yang sama dalam waktu 3 tahun berturut-turut sehingga auditee dapat mempengaruhi auditor dalam upaya pengungkapan kesalahan yang telah dilakukan atas pekerjaan yang sedang di audit.

Hal ini sejalan dengan penelitian yang dilakukan oleh Havidz dan Winarna (2010) yang menyatakan bahwa independensi memberikan pengaruh negatif terhadap kualitas hasil audit. Hasil pengujian ini tampak pada jawaban responden yang mayoritas mengisi kurang setuju dan tidak setuju pada pernyataan semua kesalahan auditee yang dilaporkan karena adanya campur tangan dari Pimpinan. Dengan kata lain semakin besar pengaruh Pimpinan, independensi auditor akan semakin tidak mempengaruhi kualitas hasil audit internal.

\section{Pengaruh Bukti Audit terhadap Kualitas Hasil Audit Internal}

Hasil pengujian hipotesis ketiga membuktikan bahwa bukti audit tidak berpengaruh terhadap kualitas hasil audit internal, sehingga $\mathrm{H}_{\text {a3 }}$ ditolak. Hal ini dikarenakan para auditee belum memiliki pengendalian intern yang efektif sehingga dokumen yang dijadikan sebagai bahan bukti yang diberikan kepada auditor pada saat pemeriksaan tidak handal. Selain itu, tidak jarang hingga tenggat waktu yang telah ditentukan oleh auditor, bahan bukti tidak juga diberikan oleh auditee. Hal ini dikarenakan memang auditee sengaja menyembunyikan bukti pertanggung jawaban yang tidak valid agar tidak terperiksa. Penyebab lainnya terkadang auditee belum selesai membuat dokumen pertanggung jawaban kegiatan yang diminta oleh auditor.

Berbeda dengan penelitian sebelumnya terkait dengan variabel bukti audit. Pada penelitian sebelumnya, bukti audit digunakan sebagai variabel dependen, namun dalam penelitian ini bukti audit digunakan sebagai variabel independen. Pada penelitian yang dilakukan oleh Yuniarti dan Tiara (2015), pengalaman dan profesionalisme memberikan pengaruh yang signifikan secara parsial terhadap kualitas bukti audit. Fitriani dan Chariri (2014) juga melakukan penelitian dengan variabel tipe klien dan tipe komuniasi yang masingmasing memberikan pengaruh signifikan terhadap pengumpulan bukti audit. Sedangkan dalam penelitian yang dilakukan oleh Kinantya (2015), bukti audit yang kompeten dipengaruhi 
signifikan oleh variabel pengalaman auditor, profesionalisme, dan resiko audit secara parsial.

Baik buruknya bukti audit yang dapat dikumpulkan oleh auditor, selain terpengaruh oleh pengetahuan langsung yang dimiliki oleh auditor, hal ini juga dapat dipengaruhi oleh beberapa aspek yaitu independensi pemberian informasi kepada auditor, efektifitas pengendalian dalam organisasi auditee, kualitas individu yang memberikan informasi, tingkat objektifitas bukti audit, dan ketepatan waktu pengumpulan bukti audit.

\section{Simpulan, Keterbatasan, dan Implikasi Hasil Penelitian}

Kesimpulan dari penelitian mengenai pengaruh kompetensi, independensi, dan bukti audit terhadap kualitas hasil audit internal adalah bahwa kompetensi memberikan pengaruh terhadap kualitas hasil audit internal. Independensi dan bukti audit tidak berpengaruh terhadap kualitas hasil audit secara parsial.

Keterbatasan dalam penelitian ini adalah peneliti tidak membedakan auditor responden berdasarkan jenjang jabatan auditor (auditor ahli, auditor pertama, auditor muda, auditor madya, pengendali teknis, dan pengendali mutu). Selain itu, variabel yang diteliti hanya kompetensi, independensi, dan bukti audit yang digunakan untuk melihat pengaruh atau tidaknya terhadap kualitas hasil audit internal.

Peneliti memberikan saran untuk penelitian selanjutnya dapat menggunakan variabel lainnya guna meningkatkan kualitas hasil penelitian. Untuk auditor Kementerian Koperasi dan UKM untuk terus meningkakan kompetensi yang dimiliki. Inspektur selaku Pimpinan Inspektorat Kementerian Koperasi dan UKM agar tidak ikut campur tangan dalam penyusunan program, pelaksanaan hingga pelaporan hasil audit. Selain itu perlu adanya tim pengendali internal di setiap Unit Kerja dan Satuan Kerja.

\section{Daftar Referensi}

Ardini, Lilis, (2010). Pengaruh Kompetensi, Independensi, Akuntabilitas Dan Motivasi Terhadap Kualitas Audit, Majalah Ekonomi, Tahun XX.

Arens, A. Alvin, et al, (2010). Jasa Audit dan Assurance, Buku 1, Edisi Bahasa Indonesia, Salemba Empat, Jakarta.

Bamber, (1993). Opportunities in Behavioral Accounting Research. Behavioral Research in Accounting, Vol. 5.

Bolang, Marietta Sylvie, dkk, (2013). Pengaruh Kompetensi, Indenpendensi dan Pengalaman Terhadap Kualitas Audit Aparat Indpektorat Kota Tomohon Dalam Pengawasan Pengelolaan Keuangan Negara, Jurnal Riset Akuntansi dan Auditing Magister Akuntansi Fakultas Ekonomi dan Bisnis Unsrat Volume 4 Nomor 2.

DeAngelo, Linda Elizabeth, (1981). Auditor Independence, 'Low Balling', and Disclosure Regulation, Journal of Accounting and Economics 3. 113-127, North-Holand.

Fitriani dan Chariri, (2014). Pengaruh Tipe Klien dan Tipe Komunikasi Terhadap Pengumpulan Bukti Audit (Studi Persepsi Auditor KAP di Jawa Tengah, Diponegegoro Journal Of Accounting Volume 3 Nomor 2.

Kinantya, Purnamasari dan Gunawan, (2015). Pengaruh Pengalaman, Profesionalisme, dan Resiko Audit Terhadap Bukti Audit Kompeten Yang Cukup. Prosiding Penelitian SPeSIA.

Mabruri, Havidz dan Winarna, Jaka, (2010). AnalisisFaktor-Faktoryang Mempengaruhi Kualitas Auditdi Lingkungan Pemerintah Daerah, Simposium Nasional Akuntansi XIII, Purwokwerto.

Mulyadi, (2010). Auditing, Jilid 1 Edisi 6, Salemba Empat, Jakarta.

Schroeder, G. Richard, et al, (2005). Financial Accounting Theory and Analysis, Edisi Kedelapan, Willey, Amerika Serikat. 
Spencer, Lyle M, and Spencer, Signe. M., (1993). Competence at Work, New York: Wiley. Suartana, I Wayan, (2010). Akuntansi Keperilakuan, Teori dan Implementasi. CV.Andi Offset, Yogyakarta.

Sukriah, Ika, dkk, (2010). Pengaruh Independensi, Pengalaman Kerja, Objektifitas, IIntegritas dan Kompetensi Terhadap Kualitas Hasil Pemeriksaan, Simposium Nasional Akuntansi XII, Palembang.
Tjun Tjun, dkk, (2012) Pengaruh Kompetensi dan Independensi Auditor Terhadap Kualitas Audit, Jurnal Akuntansi Vol 4.

Yuniarti dan Tiara, (2015). Pengaruh Pengalaman dan Profesionalisme Akuntan Forensik Terhadap Kualitas Bukti Audit Guna Mengungkap Fraud (Studi Kasus Pada Akuntan Forensik di Perwakilan BPKP Jawa Barat), Jurnal Riset Akuntansi dan Keuangan, 3 (1). 